DOI: $10.20472 / B M .2021 .9 .2 .005$

\title{
IMPACT OF ESTABLISHING THE EUROZONE ON ECONOMIC PERFORMANCE
}

\author{
JAN SKOPEČEK
}

\begin{abstract}
:
The paper focuses on the impact of deepening the European integration process or the launch of the euro on the economic performance of the European economy. It points to weak economic growth rates in European economies, thus disproving the assumption of the fathers of the common European currency that the introduction of the euro will lead to higher economic growth rates. It analyses European strategies to make the Eurozone the most competitive economic center in the world, discussing the reasons why these strategies have repeatedly failed. Furthermore, the term secular stagnation in the European context is also debated. The text also discusses the reasons for the weak economic growth of the Eurozone and points to divergent developments in European economies within the Eurozone.
\end{abstract}

\section{Keywords:}

Economic Integration, Monetary Union, Optimum Integration Area, ECB, GDP, Growth, Interest Rates, Regulation, Aggregate Labor Productivity, Cross Country Output Convergence

JEL Classification: F15, O49, K20

\section{Authors:}

JAN SKOPEČEK, Faculty of Economics, University of Economics, Prague, Czech Republic, Email: skopecek@post.cz

\section{Citation:}

JAN SKOPEČEK (2021). Impact of Establishing the Eurozone on Economic Performance. International Journal of Business and Management, Vol. IX(2), pp. 57-74., 10.20472/BM.2021.9.2.005 


\section{Introduction}

According to the European community's political elites at the time, the creation of the European economic and monetary union was intended to bring higher economic growth to this integration group. It was intended to ensure faster convergence of less developed Member States to more advanced economies. Faster convergence was supposed to be the result of the confirmation of the endogenous nature hypothesis of the optimal currency area theory (Frank and Rose, 1998). This means that the originally economically heterogeneous countries establishing the Eurozone, or the countries subsequently entering it, should have approached one another more economically faster owing to another integration jump (adoption of the common currency). Thus, the originally suboptimal currency zone was to become a group complying with the conditions defined by the theory of the optimal currency zone over time.

\section{Long-term Slowdown in the Economic Performance of the Eurozone Countries}

Neither of the above objectives has been achieved. In recent decades, the EU has been associated with efforts to deepen integration, but unfortunately it has been accompanied by increasing regulation and bureaucracy (Vaubel, 2009). These processes have caused economic growth of the EU as a whole to slow in recent decades. Over the past two decades, this decline in the growth rate of economies has been even more applicable to Eurozone countries. It turns out that there is no faster convergence in countries using the euro as their currency. On the contrary, the European economic and debt crisis triggered by the 2008 financial crisis has widened the gap between the so-called northern and southern wings of the Eurozone (Sinn, 2016). This applies not only to the average level of economic growth, but also other essential economic parameters for the common functioning of monetary policy. These processes are reflected in the growth of the inflation differential, the increase in balance of payments deficits or external imbalances, the slowdown in labour productivity growth, and the rise in unemployment. 


\section{Chart 1: Average GDP growth rates of today's Eurozone countries (\%)}

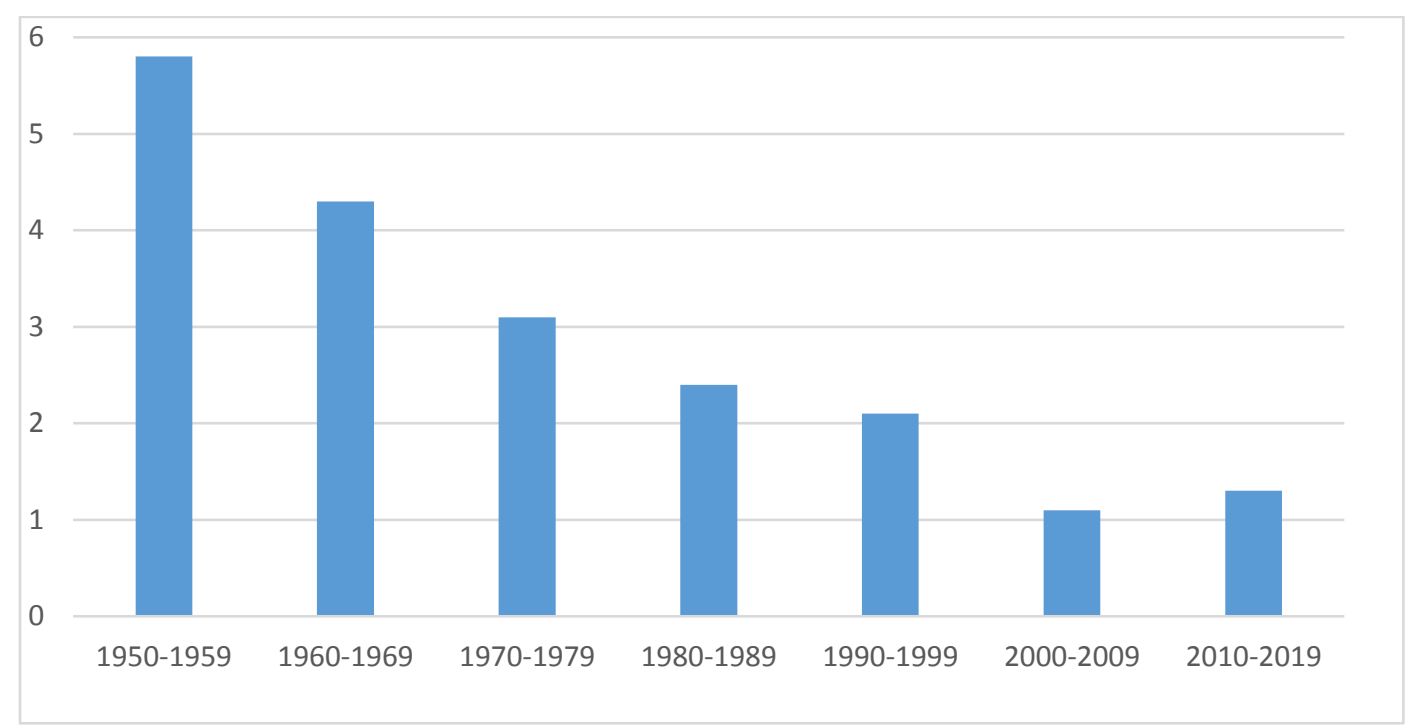

Source: Eurostat, European Commission (2021), own processing.

Chart 1 illustrates that, as the depth of the European integration process progresses, there has been a decline in the average rate of economic growth of the Eurozone countries, i.e. countries belonging to the core of the $\mathrm{EU}$, as they are frequently referred to. On average, the growth rate fell by -0.75 pp between individual decades. This is a long-term and sustained trend, not the experience of the last decade, which was triggered by the financial crisis and subsequently by the post-2008 economic crisis. It has exposed the long-term structural difficulties of the European economy. As this is a long-term trend, it cannot be attributed primarily and exclusively to the emergence of the Eurozone, but rather to a generally deepening integration process, which is accompanied with unification, excessive centralisation, and regulation. Even the introduction of the common European currency in 1999 did not reverse this long-term trend of declining European economic dynamism. On the contrary, it has contributed to the extermination of imbalances and to the divergence of many European economies. On average, Eurozone countries have grown more slowly than the rest of the EU in the long-term. In terms of economic performance, the Eurozone and the EU as a whole have long lagged behind the US, with which it is most frequently compared. If we wish to compare the Eurozone or the EU as a whole with fast-growing new global economies such as China or India, the Eurozone shows even worse results: see Chart 2. 


\section{Chart 2: GDP growth rates of selected economic centres (\%)}

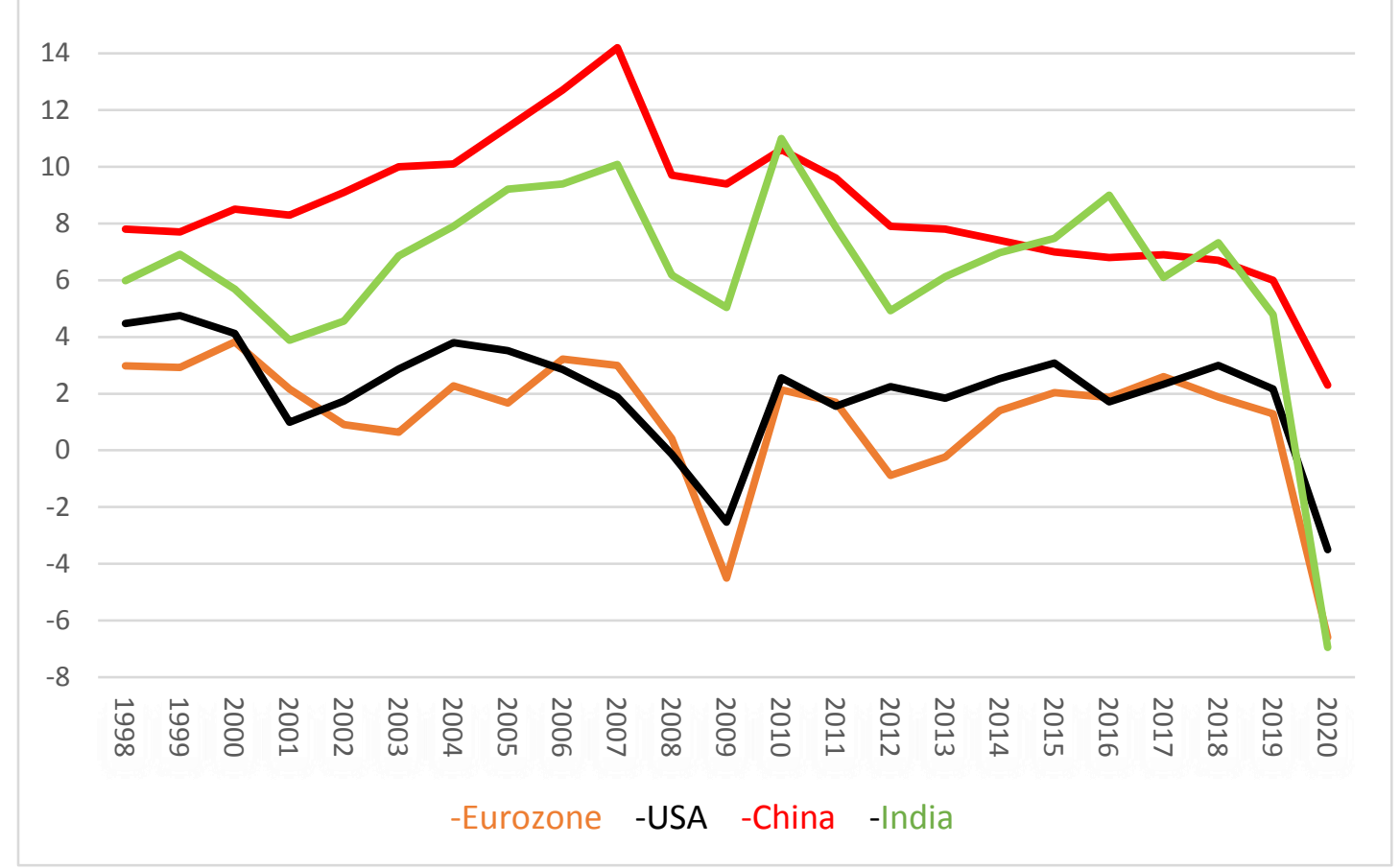

Source: OECD (2021), own processing.

\section{The Lisbon Strategy as an Attempt to Transform the EU Economy}

However, the weak economic performance of the countries participating in the European integration project was a theme long before the financial and economic crisis after 2008. Following not entirely successful attempts to address this situation during the $1990 \mathrm{~s}$, the EU adopted a very ambitious plan at the beginning of the new millennium in the form of a socalled Lisbon Strategy, which aimed at "a radical transformation of the European economy" (EC, 2000; p1). The need for any such strategy for a transformation of the European economy through the Lisbon Strategy was demonstrated by Urban (2010), who at the time of its adoption summarised the main causes of Europe's poor economic performance as follows:

"1. In Europe, few people are drawn into the labour force: the employment rate in the US is higher than in the EU (81.7\% vs. $63.4 \%$ in 1999). Women's employment is also lower in Europe;

2. Europe has a problem with the development of labour productivity: since the mid1990s, US gains have been higher, associated with the slow introduction of new technologies in Europe, low $R \& D$ spending, weak innovation activity, and barriers to 
entrepreneurship. The new knowledge economy has not yet become a driver of economic growth in Europe;

3. Europe works less: in 2002, on average, 1,815 hours were worked annually in the US, compared with only 1,340 hours in the Netherlands, for example" (Urban, 2010).

The Lisbon Strategy was adopted at the European Council summit in spring 2000 and set out an ambition for the EU: "to become the most competitive and dynamic knowledgebased economy in the world capable of sustainable economic growth with more and better jobs and greater social cohesion." (EC, 2000; p.1). The EU should have achieved this strategic objective by moving to a knowledge-based economy and society through information society and R\&D policies, as well as by accelerating the structural reform process for competitiveness and innovation, completing the internal market, modernising the European social model, an appropriate mix of macroeconomic policies, etc. Later, the Lisbon Strategy included an environmental element or an element concerned with sustainable development and the quality of life. The Lisbon Strategy was thus based on three pillars: economic, social and environmental. Each of these pillars then contained the objectives to be achieved and a set of individual measures (NF, 2012). According to the Lisbon summit conclusions, the implementation of the measures set out in the Lisbon Strategy was intended to bring a realistic outlook for the coming years to an average economic growth rate of around 3\% (EC, 2020). This was far from being achieved (see Chart 1). As early as spring 2004, the European Council called for an evaluation report on the achievement of the Lisbon Strategy objectives, and the Wim Kokova EC Report (2014) was drafted. It was critical of the fact that the objectives set out in the Lisbon Strategy have not been achieved and the EU has lagged behind both the US and Asia in economic growth in recent years, European economies are facing an ageing population, a decline in the workforce, a poor budgetary position, etc. It criticises the Lisbon Treaty and blames its failure on the overly fragmented agendas, the contradiction of the various objectives, but also the failure on the part of the Member States to adopt politically unpopular reforms. It calls for increased productivity and job growth through urgent action in the fields of the knowledge-based society, the single market, the labour market, the business environment and environmental sustainability (EC, 2014). Although new revisions and updates to the Lisbon Strategy followed in the years to come, it has never been able to even get close to the original objectives and declared ambitions to become the most competitive and knowledge-based and innovation-based economy within 10 years, overtaking the USA in its performance.

In this respect, Ševčíková and Ševčík (2005) state: "Unfortunately, the Lisbon Strategy... has set itself completely unrealistic objectives. In the light of the statistical data at the time, the "ideological" objective in particular appears to be a complete utopia, when the EU 
was supposed to overshoot the US in economic growth rates, thus becoming the most competitive and dynamic economy in the world capable of "sustainable economic growth", all by 2010 ..., even though the Lisbon Strategy talks about improving the business environment, at the same time foresees new harmonisation and regulation. So would it not be easier and more effective to eliminate issues related to economic growth, for example by removing the remaining barriers to the internal market, and to promote economic development with a low or at least lower tax burden? What the EU and, above all, its citizens need is less regulation and economic restrictions and more freedom in the area of free movement of labour, services, capital and investment. European Union citizens would be helped by a return to the EU's original objectives and the elimination of efforts to regulate all sorts of things, which was started by Jacques Delors, when he became the President of the European Commission in 1985" (Ševčíková and Ševčík, 2005; p. 11-12).

However, the Treaty of Lisbon was not the only drowning project of EU political leadership. Even after its failure, it came up with a similar document called Europe 2020: Strategy for Smart, Sustainable and Inclusive Growth (EC, 2010). This post-2008 crisis response material also aims to achieve recovery or growth through reforms, based on knowledge and innovation, a more environment-friendly, economy less dependent on resources, an economy with high employment, and a socially and territorially coherent economy (EC, 2010). I believe that such documents are doomed to fail primarily because they contain conflicting objectives in the economic policy. European economies, or European governments, and the EU's political leadership are unwilling to accept that higher competitiveness and faster economic growth cannot be achieved if European economies continue to insist and defend the European social model or the European welfare state. The level of social expenditure, together with an over-regulated and overly protective labour market for employees, leads to a loss of motivation in European economies and a strengthening of the so-called merit society. This has been amplified in recent years, at least since the Lisbon Strategy, which included the environmental element in its objectives, by a large increase in environmental regulations reducing the competitiveness of European industrial producers and energy companies in particular.

\section{Great Recession and Fears of Secular Stagnation}

The so-called Great Recession following the 2008 financial crisis affected almost the entire developed world, including the Eurozone. If we analyse the depth of the economic downturn, the time needed to return to pre-crisis levels, the level of economic growth in the post-crisis period, and other economic indicators, we find that the Eurozone's ranking compares very unflatteringly with other regions or economic centres. As stated by Babecká 
Kucharčuková, and Brůha (2018; p. 13), "the Eurozone’s performance fell by $4 \%$ in real terms in 2009 and the unemployment rate approached 10\%. Globally, the GDP of high-income economies fell by 3.4\%, which represents the double of the decline in global GDP in the specific year". The depth of the Eurozone's decline, or longer-term issues, is recognised by Stiglitz (2017; p. 79), who points out that the Eurozone has fared worse than the USA, but also the rest of Europe. "The Eurozone's downturn has lasted eight years and Europe is unlikely to return to any massive growth any time soon. It is already clear that Europe is facing a lost decade, and there is a risk that in a few years we will be talking about a lost quarter of a century of Europe... The fact that the Eurozone is doing so much worse than other countries, including seemingly similar countries, indicates that there is a common cause for the Eurozone's woes: the euro."

\section{Chart 3: Development of the Eurozone's GDP in billions of euro (in 2010 prices)}

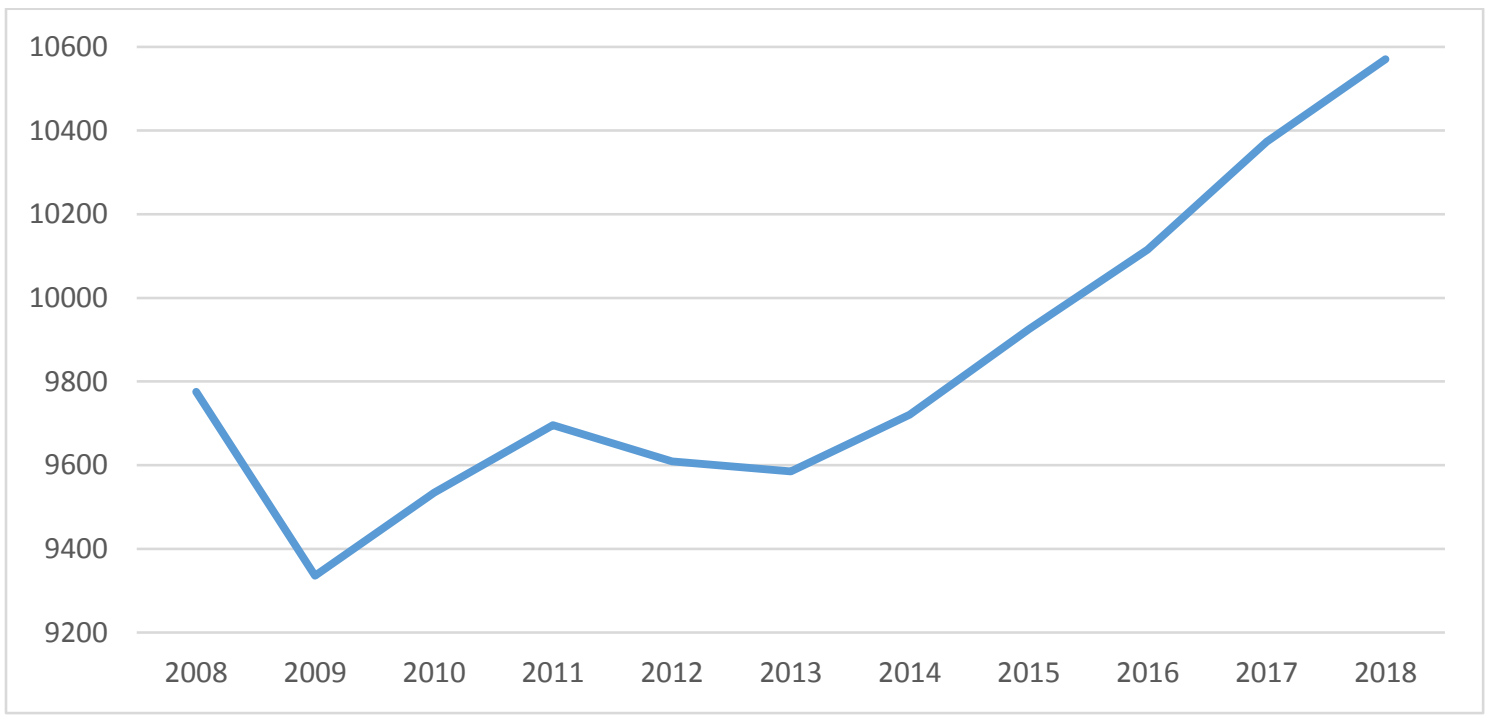

Source: Eurostat (2020), own processing.

It is not just the depth of the Eurozone's economic downturn in the so-called Great Recession. It is also about the ability or inability of economies using the euro to emerge from the economic recession and build on it with robust economic growth. Some economists have even reincarnated the term "secular stagnation" (Summers, 2014) in the context of the Eurozone's inability, as well as the USA, to return to robust economic growth after crisis years. The term secular stagnation means the need for negative real interest rates to achieve balanced savings with investment at full-employment production levels (Teulings and Baldwin, 2014).

In the context of post-crisis developments, the point was that there was only a slow and weak recovery in the USA, but especially in European economies, at the cost of a very loose monetary policy, which, even after hitting the zero interest rate threshold (see Chart 5 ) had to 
proceed to unconventional monetary policy instruments, in particular the so-called quantitative easing. With respect to the long-term absence of inflationary pressures despite the extremely loose monetary policy and with respect to demographic developments in the so-called Western societies with an impact on the labour market, the structure of factors of production, as well as the expected growth of aggregate savings, with simultaneous weak investment demand, there are increasing doubts as to whether the previously known and used standard reservoir of macroeconomic policy instruments is definitely exhausted and needs systemic redefinition. This does not apply to monetary policy instruments only, but also fiscal policy instruments, given the ever-narrowing space for the active, stabilising fiscal policy function due to the high debt of most advanced economies and pressures from an aging society.

\section{Chart 4: Development of key interest rates of selected central banks (\%)}

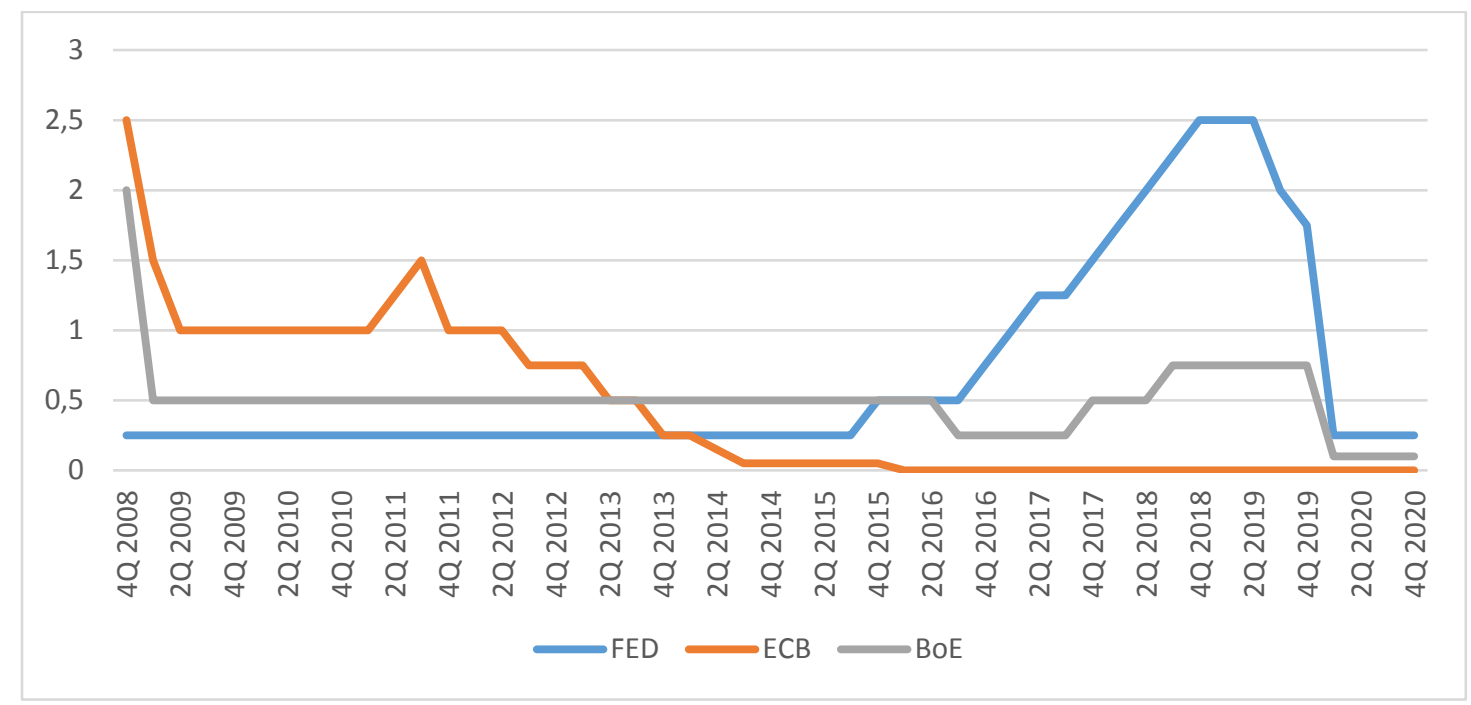

Source: $E C B, F E D$, and BoE (2021), own processing.

I dare say that the academic debate on the need to redefine the set of instruments of the monetary policy in particular, has not been definitively solved by the economic-policy practice of the endless use of unconventional monetary policy instruments or quantitative easing by central banks, more than a decade after the financial and debt crisis. This also applies to the crossing of the previously prohibited line between the monetary and fiscal policy, where quantitative easing takes place through the purchase not only of corporate securities, but also of government bonds. In order to allow further debt financing for governments, the central banks (especially the ECB) are monetising the national debt. While the actors point out that this is not a direct purchase of government bonds by central banks, it is a buy-out on secondary markets. Yet experts know that the ECB has also intervened through direct purchases of government bonds. These are, in my view, non-standard or even revolutionary changes in the use of macroeconomic policy instruments. In addition, they were not used only 
for the short-term or temporarily following the crisis, as shown in Chart 5, but unfortunately they are also the standard of operation of economic and political institutions at the beginning of the third decade of the $21^{\text {st }}$ century. In this manner, we can consider the redefinition of standard macroeconomic policy instruments to be implemented.

\section{Chart 5: Volume of assets of selected central banks in national currencies (100 million yen, millions of euros, and millions of dollars)}

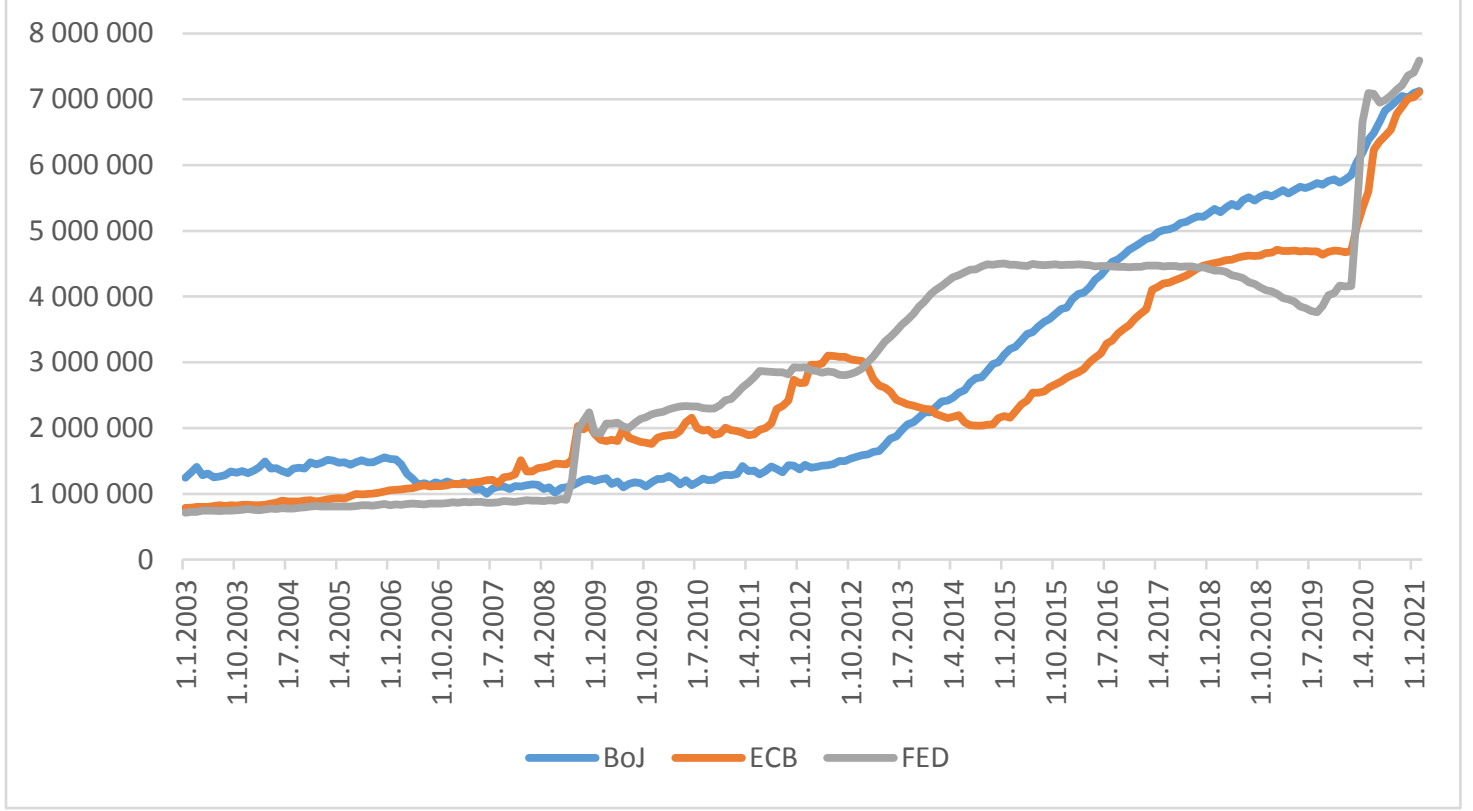

Source: ECB (2021), Fed (2021), and BoJ (2021), own processing.

Note: this is a statement in nominal values.

There is no consensus among economists on the adequacy of the use of the adjective "secular" in the context of the stagnation of European economies after 2008. In search of the causes of this stagnation or long-term low economic growth rates, what is most frequently mentioned is the issue of low productivity growth in European economies, a declining share of the economically active part of the population, or low investment activity. Some perceive slow innovation, an over-regulated business environment, or the aforementioned over-the-top welfare state as the reasons.

The loss of dynamics also applies to OECD countries. Labour productivity growth remains at a very low level in advanced OECD countries. Since 2010, productivity growth has slowed to $0.9 \%$, half the level recorded in the pre-crisis period, and remains below the historical average (OECD, 2018). Even lower labour productivity growth compared to the group of the most advanced countries is recorded separately in the Eurozone countries (see Chart 6). 


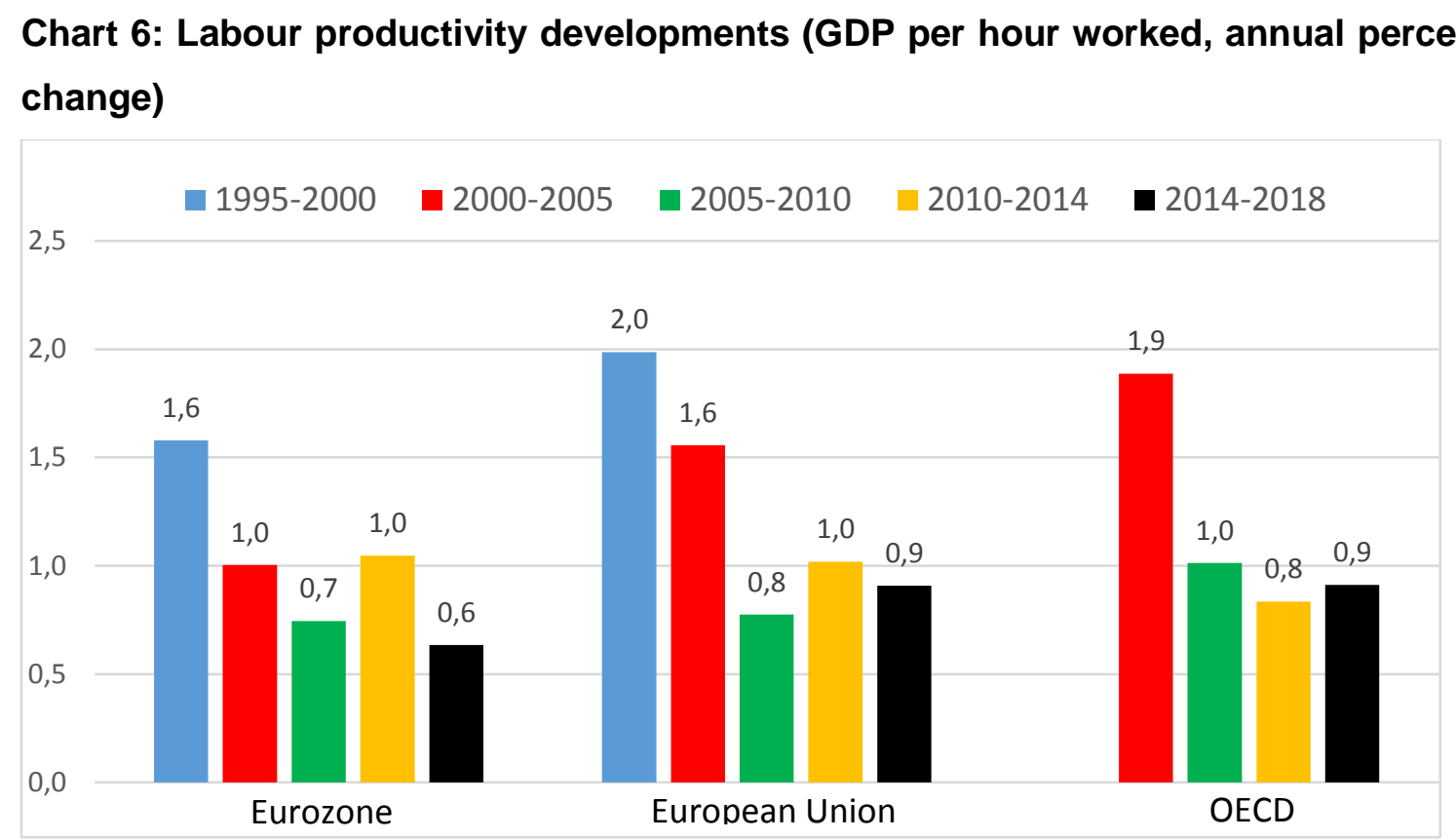

Source: OECD (2019), own processing.

Yet low labour productivity growth in advanced economies was not observed until the arrival of the financial and subsequent economic crisis of 2008. Labour productivity growth has been slowing continuously since the 1970s. Gordon (2012) explains slow growth by exhausting important inventions. He attaches greater importance to electricity or the combustion engine in terms of labour productivity. These, in his view, have been more important in raising productivity and living standards than anything produced by the development of computer technology known as the "dot.com boom". He also adds that there is no great invention on the horizon comparable to the above (Gordon, 2012). Eichengreen (2014) disagrees with this explanation of slow productivity growth and the cause of secular stagnation, seeing great potential in the development of robotics and the human genome, in which he argues we are only at the beginning. He recalls that even in Gordon's golden age of technological development, there were periods of slow productivity growth, especially when new networked technologies were being introduced, yet the economy had not yet adjusted to their availability. That is why, in his view, there is no need to worry about the current low productivity growth when we are only on the verge of the robot and gene revolution.

The Eurozone has also recorded a lower level of investment activity in the long term, as measured by the share of investment in the GDP. Jimeno, Smets, Yiangou (2014) cite several reasons why this is most likely not just a cyclical phenomenon, but a structural problem. They cite rising capital costs caused by stricter financial regulation as one of the reasons. This cannot be offset by interest rates, even if they were zero. The over-debt faced by both banks and firms in the Eurozone serves as an important aspect of the lower level of investment 
activity. Relatively low productivity is also essential. The authors argue that it is not a question of whether the current trends exist or not, but whether they are secular or whether the trend of falling equilibrium interest rates can be reversed. They propose measures, particularly on the supply side, yet arguing that these are the necessary steps to revive investment demand. The authors stress that it is the European region that has the greatest potential to benefit from structural reforms. While demographic trends leading to an increase in the share of people over 65 in the economically active part of the population are difficult to reverse and have long inertia, higher productivity can be achieved through appropriate economic and political measures. In particular, the authors come up with a proposal for reforms or transformation of the financial system, which, in addition to the process of debt relief of private entities, including banks, is intended to include measures to reduce the costs of mediation or the cost of capital. They perceive great potential in the European region in the development of venture capital, which plays a weak role in the European financial system compared to, for example, the USA. In their view, another possibility consists in greater integration of Europe's fragmented financial sector. Therefore, they perceive great potential in completing a capital union within the EU (Jimeno, Smets, Yiangou, 2014).

The authors cited above themselves acknowledge that reducing the cost of capital is not self-sustaining without sufficient investment opportunities. Yet their over-emphasis on reforms of the financial system appears to me to be too narrow a view. As much as a more efficient European financial system can contribute to higher economic growth in our region, in my view, there is a need to address other, long-term structural issues in European economies. These are, in addition to an inflexible and overprotective labour market, the oversized, generous European social models, or the so-called social welfare state. Both of these aspects lead to demotivation of the workforce and further exacerbate the imbalances in public finances in most European countries. This in turn causes the debt trap of European economies to deepen. Similar structural problems in the Eurozone are noted by Thimann (2006), who identifies the high unemployment rate as a fundamental problem of the Eurozone crisis. The lack of capacity to create enough jobs in the Eurozone is perceived not in the insufficient level of demand, but in the high wage costs relative to the level of productivity, the high level of taxation and social contributions, and an overly regulated business environment (Thimann, 2006).

The aforementioned long-term structural imbalance in public finances, or the enormous indebtedness of European economies, is another factor limiting the growth potential of European economies. Last but not least among the main structural problems, it is necessary to mention the over-regulation of European economies. The above-mentioned structural problems of European economies also apply, to a lesser extent, to the Czech Republic. I discuss this in more detail, together with other authors, e.g. in Klaus et al. (2013). 


\section{Overregulation of European Economies}

Many authors draw attention to the overregulation of European economies, as well as to the potential that possible deregulation can bring. According to Kovac and Vandenberghe (2020), overregulation has the potential to disrupt the market, undermine productivity, or reduce the growth rate. In addition to the golden rule that regulation should only be imposed in the case of market failure and provided that its benefits outweigh its costs, for an effective level of harmonisation and subsidiarity in EU decision-making, the authors recommend a thorough examination of the costs and benefits of harmonisation policies, which should lead to a better and more efficient vertical allocation of agendas between the EU and Member States (Kovac and Vandenberghe, 2020). Lower levels of regulation reduce the scope for the so-called grey economy. According to Enste (2010), this will support the necessary structural changes in the legal part of the economy. In his view, deregulation is even an alternative to tax cuts, which are difficult given the need to secure public goods and the social system (Enste, 2010).

In analysing the optimal level of regulation, economic theory encounters a lack of hard data. We are thus referred to the comparison of individual legal systems, or norms governing regulations, or to various indices that attempt to quantify and compare the harshness or severity of regulations. The World Bank's "Doing Business" index is an example of this composite index. This index measures and assesses the regulation of the business environment among 190 countries. The Doing Business Index covers 12 areas of business environment regulation: starting a business, building regulation, availability of electricity, access to credit finance, complexity of protecting minority investors, tax environment, movement of goods across borders, ease of disposing of assets, enforceability of contracts, dealing with insolvency, employment regulation, and government contracts.

Table 1 shows the ranking of countries and the scores achieved by Eurozone Member States in competition with 190 countries. The table unambiguously shows that not a single Eurozone Member State is among the top ten countries with the most business-friendly regulatory environment. There are four European countries in the top ten, Denmark in the fourth place, the United Kingdom in the eighth place, Norway in the ninth place, and Sweden in the tenth place. It is significant that none of these European countries belonging to the "TOP 10" are part of the Eurozone and two of them do not belong to the European Union. The main reason for the UK's departure from the EU was precisely the diminishing ability to decide on legal norms, including the regulatory environment, according to its own interests. 
Table 1: Ranking of Eurozone countries in the 2020 Doing Business index

\begin{tabular}{|l|c|c|}
\hline & Ranking & $\begin{array}{l}\text { DB } \\
\text { score }\end{array}$ \\
\hline Lithuania & 11 & 81.6 \\
\hline Estonia & 18 & 80.6 \\
\hline Latvia & 19 & 80.3 \\
\hline Finland & 20 & 80.2 \\
\hline Germany & 22 & 79.7 \\
\hline Ireland & 24 & 79.6 \\
\hline Austria & 27 & 78.7 \\
\hline Spain & 30 & 77.9 \\
\hline France & 32 & 76.8 \\
\hline Slovenia & 37 & 76.5 \\
\hline Portugal & 39 & 76.5 \\
\hline Netherlands & 42 & 76.1 \\
\hline Slovakia & 45 & 75.6 \\
\hline Belgium & 46 & 75 \\
\hline Cyprus & 54 & 73.4 \\
\hline Italy & 58 & 72.9 \\
\hline Luxembourg & 72 & 69.6 \\
\hline Greece & 79 & 68,4 \\
\hline Malta & 88 & 66.1 \\
\hline Source: World Bank
\end{tabular}

Source: World Bank (2021), own processing.

The competitor which the EU aimed to catch up with through the Lisbon Strategy, the USA, is in fourth place with an index of 84.0. Even China, to which the adjective communist is added, ranked as the 31st in the regulatory environment for business, with an index score of 77.9. It is thus ahead of a number of Eurozone Member States, including the large, founding members of the integration group. Of course, the ranking takes into account selected parameters of economic freedom, while abstracting from political freedom.

The fact that a number of Eurozone Member States are in an unflattering position in this ranking is a reflection of the low competitiveness of these economies. This is a particularly important problem for Eurozone Member States because, as Ševčíková (2014) points out in this context, if the less competitive countries, especially those in the southern part of the Eurozone, were not members of the monetary union, they could devalue their currency and thus increase their competitiveness. However, as part of a monetary union, they are condemned to internal devaluation through a fall in real wages and pensions. We have the experience that membership in the monetary union, or the renunciation of the possibility to carry out so-called competitive devaluations, did not become a motivation to carry out structural reforms in order to increase or maintain its competitiveness, as some have thought, see e.g. (Duval and Elmeskov, 2005). 
The ranking also shows a high degree of heterogeneity in the regulatory environment for business in the Eurozone. This is surprising with respect to the decades of ongoing harmonisation of the legal environment within the EU, including the Eurozone. Moreover, the countries with the best scores in the Eurozone group are not its founding members, but are post-Soviet economies that have had to go through a transition. With its $41^{\text {st }}$ place and an index value of 76.3, the Czech Republic would rank below average among Eurozone countries.

The above ranking therefore indicates that the Eurozone is not made up of countries which excel in terms of the friendliness of the regulatory environment for business compared to other economies. The World Bank's ranking suggests that despite years of harmonisation of Eurozone Member States' laws, there are significant differences between countries in such a key area for economic development. In addition, it is not the case that the so-called old, founding Member States of the Eurozone have an optimal regulatory environment for new Member States and potential new Eurozone members to follow. Thus, one may agree with some of the authors quoted above who, similarly to the OECD, perceive the implementation of important structural reforms of European economies as necessary for the future economic growth of the Eurozone.

\section{Eurozone's Heterogeneity}

It is obvious that the original objective, which was to lead to higher growth rates in economies with the euro as the currency, has not materialised. Another assumption that after the creation of the Eurozone, the Member States would converge faster, has not materialised, either. This was also the argument of the so-called endogenous theory of optimal currency zones, which says that a suboptimal currency zone becomes optimal in the course of its operation. Table 2 also confirms that the Eurozone countries are not converging but diverging. Instead of narrowing the differences between Member States, they are widening. The dividing line is between the north and the south of the Eurozone, which already includes France. This is not only in terms of the economic level, but also in terms of the state of public finances. The original problem that many economists pointed out, i.e. that the Eurozone was made up of too many economically heterogeneous countries, has not disappeared, but on the contrary has become even worse after the economic crisis that started in 2008.

Table 2: Development of the relative economic level by GDP/capita (EU27=100)

\begin{tabular}{|l|l|l|l|l|l|l|l|l|}
\hline & 2000 & 2005 & 2010 & 2015 & 2016 & 2017 & 2018 & 2019 \\
\hline Eurozone & 119.1 & 114.7 & 110.1 & 107.5 & 107.4 & 107.0 & 106.6 & 106.1 \\
\hline $\begin{array}{l}\text { Czech } \\
\text { Republic }\end{array}$ & 73.3 & 82.1 & 84.4 & 88.8 & 89.0 & 91.1 & 92.3 & 92.7 \\
\hline
\end{tabular}




\begin{tabular}{|l|l|l|l|l|l|l|l|l|} 
Belgium & 125.6 & 123.5 & 121.1 & 120.9 & 119.8 & 118.3 & 118.1 & 117.9 \\
\hline Germany & 124.1 & 120.0 & 120.6 & 124.6 & 124.7 & 124.2 & 123.2 & 120.4 \\
\hline Estonia & 42.5 & 61.7 & 66.2 & 77.1 & 77.9 & 79.5 & 81.6 & 83.8 \\
\hline Ireland & 136.4 & 150.5 & 131.6 & 181.0 & 177.0 & 184.7 & 190.7 & 193.0 \\
\hline Greece & 88.2 & 95.2 & 84.9 & 69.9 & 67.7 & 67.2 & 66.6 & 66.5 \\
\hline Spain & 97.6 & 102.7 & 96.4 & 91.4 & 92.0 & 92.8 & 91.5 & 91.0 \\
\hline France & 117.9 & 113.5 & 109.2 & 106.9 & 105.7 & 104.3 & 104.2 & 106.1 \\
\hline Italy & 122.4 & 111.7 & 105.9 & 96.6 & 98.5 & 97.5 & 96.7 & 95.7 \\
\hline Cyprus & 96.2 & 103.3 & 101.6 & 83.3 & 88.1 & 89.2 & 90.8 & 89.5 \\
\hline Latvia & 36.3 & 51.7 & 53.6 & 65.3 & 65.9 & 67.2 & 69.1 & 69.0 \\
\hline Lithuania & 38.2 & 54.0 & 61.1 & 75.5 & 76.3 & 79.2 & 81.5 & 83.5 \\
\hline Luxembourg & 249.7 & 253.6 & 260.0 & 271.6 & 271.9 & 263.1 & 261.2 & 260.0 \\
\hline Malta & 83.0 & 83.0 & 87.3 & 98.0 & 98.3 & 99.9 & 99.6 & 100.6 \\
\hline Netherlands & 144.0 & 140.0 & 137.0 & 131.6 & 128.9 & 129.2 & 129.8 & 128.2 \\
\hline Austria & 132.8 & 130.4 & 127.8 & 130.7 & 129.9 & 127.1 & 128.0 & 126.4 \\
\hline Portugal & 85.3 & 84.6 & 82.9 & 77.6 & 77.9 & 77.5 & 78.3 & 79.5 \\
\hline Slovenia & 81.3 & 88.8 & 84.6 & 82.8 & 83.7 & 85.6 & 87.4 & 88.7 \\
\hline Slovakia & 51.3 & 61.8 & 76.0 & 78.3 & 73.1 & 70.6 & 70.7 & 70.2 \\
\hline Finland & 121.1 & 119.3 & 118.4 & 111,2 & 110.8 & 111.6 & 111.6 & 111.1 \\
\hline SourCe: Euros & 12021 & $0 W n$ & & & & & \\
\hline
\end{tabular}

Source: Eurostat (2021), own processing.

Note: GDP per capita by PPS.

According to many authors, divergent development is not surprising. As Janáček (2020) argues, the belief that the Eurozone will contribute to the convergence of its members has underestimated the fact that in a heterogeneous monetary union, the euro exchange rate must have a different impact on countries with different economic conditions and economic cultures. Financial markets quickly assessed all Eurozone countries as equally risky, which, especially for the southern countries, meant falling nominal interest rates and, together with their higher inflation rates, even lower real interest rates. Capital flowed from the northern countries to the south, and with it goods, leading to persistent trade and balance of ayments deficits as further evidence of the growing divergence of the euro area (Janáček, 2020). Bonatti (2017) points out that the competitiveness gap between the north and south of the Eurozone was already growing before the debt crisis, only the impact on incomes and the labour market in the southern countries was masked by operating on debt. After the crisis, the gap in income and labour market performance between North and South is widening further. The widening structural divide between the north and south of the Eurozone has led to growing tensions between member states over economic policies and increased hostility towards European institutions (Bonatti, 2017). In the case of Slovenia and Slovakia, for example, convergence or divergence slowed down even after EU accession. 


\section{Conclusion}

The performance of European economies has been poor in the long-term. The idea of the Eurozone's spiritual fathers that the introduction of a common European currency would be a boost to economic growth has not materialised. Furthermore, following the introduction of the euro, the process of economic convergence of Eurozone Member States did not take place, but on the contrary, their economic heterogeneity began to deepen. European economies have not been helped by various European strategies aimed at making the Eurozone the most competitive economic region, such as the Lisbon Strategy, since the deepening of the integration process has been accompanied by a greater degree of centralisation, unification and harmonisation, which has complicated the regulatory environment in the European region rather than simplifying it. This, together with an inflexible labour market, an oversized European social model and an over-regulated business environment, is the reason for the low economic growth rates of European economies compared to other economic centres. This will not change until the individual Eurozone countries implement real structural reforms to address the structural problems of the European economies cited above. 


\section{References}

BABECKÁ KUCHARČUKOVÁ, Oxana; BRŮHA, Jan, 2018. Heterogenita pokrizového vývoje v zemích EU [Heterogeneity of Post-crisis Developments in EU Countries]. In: Global Economic Outlook April 2018. [accessed on 20 March 2019]. Available from: https://www.cnb.cz/export/sites/cnb/cs/menovapolitika/.galleries/gev/gev 2018/gev 2018 04.pdf

DUVAL, Romain and ELMESKOV, Jörgen, 2006. The Effects of EMU on Structural Reforms in Labour and Product Markets. ECB Working paper series No. 596.

EICHENGREEN, Barry, 2014. Secular Stagnation: A Review of the Issues. In: TEULINGS C., BALDWIN R.: Secular Stagnation: Facts, Causes, and Cures. A VoxEU.org eBOOk. London: CEPR Press. ISBN: 978-1-907142-77-2. [accessed on 24 March 2019]. Available from: https://voxeu.org/content/secularstagnation-facts-causes-and-cures

ENSTE, Dominik H., 2010. Regulation and Shadow Economy: Empirical Evidence for 25 OECDcountries. Constitutional Political Economy. [accessed on 10 April 2019] Available from: https://www.researchgate.net/publication/225658388 Regulation and shadow economy Empirical e vidence for 25 OECD-countries

EUROPEAN COMMUNITIES, 2014. Facing the challenge. The Lisbon strategy for growth and Employment. Report from the High Level Group chaired by Wim Kok. Luxembourg: Office for Official Publications of the European Communities. ISBN 92-894-7054-2. [accessed on 24 March 2019]. Available from: https://op.europa.eu/en/publication-detail/-/publication/88b6bc81-e3ad-4156-960f$\underline{\mathrm{f} 549369 \mathrm{aa} 9 \mathrm{~d} 4}$

EUROPEAN COUNCIL, 2000. Presidency Conclusion Lisbon European Councel 23 and 24 March 2000. [accessed on 20 March 2019]. Available from: https://www.consilium.europa.eu/media/21038/lisbon-european-council-presidency-conclusions.pdf

EUROPEAN COMMISSION, 2010. Europe 2020: Strategy for Smart, Sustainable and Inclusive Growth. Communication from the Commission. [accessed on 26 March 2019]. Available from: https://eurlex.europa.eu/legal-content/CS/TXT/PDF/?uri=CELEX:52010DC2020\&from=CS

FRANKEL, Jeffrey A.; ROSE, Andrew K., 1998. The Endogenity of the Optimum Currency Area Criteria. The Economic Journal, vol. 108, No. 449, pp. 1009-1025.

GORDON, Robert J., 2012. Is US Economic Growth Over? Faltering Innovation Confronts the Six Headwinds. NBER Working Paper No. 18315.

JIMENO, Juan F.; SMETS, Frank, YIANGO, U Jonathan, 2014. Secular Stagnation: $A$ view from the Eurozone. IN: TEULINGS C., BALDWIN R.: Secular Stagnation: Facts, Causes, and Cures. A VoxEU.org eBOOk. London: CEPR Press. [accessed on 28 March 2019]. ISBN: 978-1-907142-77-2. Available from: https://voxeu.org/content/secular-stagnation-facts-causes-and-cures

KLAUS, Václav, 2013. Česká republika na rozcestí: čas rozhodnutí [Czech Republic at a Crossroads: Decision Time]. Prague: Fragment. ISBN 978-802-5320-235.

KOVAC, Mitja and VANDENBERGHE, Ann-Sophie, 2020. Over-regulation, Degradation of the Rule of Law and Implementation of Sustainable Practices. In: ŽABKAR, V. AND REDEK, T. (Ed.) Challenges on the Path Towards Sustainability in Europe, Emerald Publishing Limited, Bingley, pp. 271-295

FACULTY OF ECONOMY, PRAGUE UNIVERSITY OF ECONOMICS AND BUSINESS, 2012. Economic Policy. The European Union's economic policy from the perspective of public choice theory and selected chapters of EU policies. Course material prepared within the OPPA project 
CZ.2.17/3.1.00/32102. Prague. [accessed on 25 March 2019] Available from: https://khp.vse.cz/wpcontent/uploads/page/344/Hospodarska politika.pdf

OECD, 2020. OECD Employment Outlook 2020: Worker Security and the COVID-19 Crisis, OECD Publishing, Paris. [cit. 15.7.2020]. Available from: https://doi.org/10.1787/1686c758-en

SINN, Hans-Werner, 2016. V pasti eura [Trapped by the Euro]. Brno: Centre for the Study of Democracy and Culture (CDK). ISBN 978-807-3253-943.

STIGLITZ, Joseph E., 2017. Euro - Společná měna jako hrozba pro budoucnost Evropy [Euro Common currency as a threat to Europe's future]. Prague: Euromedia Group. ISBN 978-80-242-58751.

SUMMERS, Lawrence, 2014. "US Economic Prospects: Secular Stagnation, Hystersis and the Zero Lower Bound", speech delivered to the National Associationfor BusinessEconomnics, Economic Policy Conference, 24 February 2014. [accessed on 28 March 2019]. Available from: http://larrysummers.com/wp-content/uploads/2014/06/NABE-speech-Lawrence-H.-Summers1.pdf

ŠEVČíKOVÁ, Michaela; ŠEVČíK, Miroslav, 2005. Lisabonská strategie: úspěch čí blamáž eurokratů? [Lisbon Strategy: success or bluff of Eurocrats?] International Politics 8/2005 YEAR XXIX. ISSN 05437962. [accessed on 22 March 2019]. Available from: https://www.iir.cz/mezinarodni-politika-8-2005lisabonska-strategie-nove

ŠEVČíKOVÁ, Michaela, 2014. Analysis of the Causes and Sequences of the Five Crises of the European Integration Process in the Context of Economic and Political Developments Following the Signing of the Maastricht Treaty. Dissertation, University of Economics and Business, Prague.

TEULINGS, C.; BALDWIN, R., 2014. Secular Stagnation: Facts, Causes, and Cures. A VoxEU.org eBOOk. London: CEPR Press. ISBN: 978-1-907142-77-2.

THIMANN Christian, 2015. The Microeconomic Dimensions of the Eurozone Crisisand Why European Politics Cannot Solve Them. The Journal of Economic Perspectives. Vol. 29, No. 3 (Summer 2015), pp. 141-163.

URBAN, Luděk, 2010. Lisabonská strategie [Lisbon Strategy]. Euroskop. [accessed on 22 March 2019]. Available from: https://www.euroskop.cz/8742/sekce/lisabonska-strategie/

VAUBEL, Roland, 2009. Evropské instituce jako zájmová skupina: dynamika stále těsnější unie [European Institutions as an Interest Group: the Dynamism of an Ever Closer Union]. Prague: Center for Economics and Policy (CEP). ISBN 978-80-86547-83-1. 